\title{
Does TPACK Mastery Affect Teamwork Skills? A Causal-Comparative Study of Pre-Service Physics Teachers
}

\author{
Yudi Guntara $^{1 *}$, Tubagus Hafid ${ }^{2}$, Indah Fatika Sari ${ }^{3}$ \\ ${ }^{1,2,3}$ Department of Physics Education, Universitas Sultan Ageng Tirtayasa, Banten, Indonesia \\ *Corresponding Address: guntaray@untirta.ac.id
}

\begin{tabular}{l}
\hline \hline Article Info \\
\hline Article history: \\
Received: February $8^{\text {th }}, 2021$ \\
Accepted: April $25^{\text {th }}, 2021$ \\
Published: April $30^{\text {th }}, 2021$ \\
\hline
\end{tabular}

Keywords:

Causal-comparative;

Preservice physics teacher;

Teamwork skills;

TPACK.

\begin{abstract}
Physics teachers need to mastery TPACK and teamwork skills because they were essential in work. The purpose of this study was to determine the relationship between TPACK mastery and teamwork skills. The research method used a causal-comparative. The sampling technique used was purposive sampling. The sample consisted of 33 preservice physics teachers from Universitas Sultan Ageng Tirtayasa and Universitas Mulawarman. The data collection method used a questionnaire and an instrument in the form of a questionnaire with a Likert scale in a web-based survey. This instrument is used to measure TPACK and teamwork skills. Data analysis techniques used Pearson's correlation and regression analysis. The results showed no significant relationship between mastery of TPACK and teamwork skills, as indicated by Pearson's correlation value of 0.061 with a significance of 0.735 . However, if further tested based on every aspect of the two variables, there is a significant correlation between technology knowledge (TK), technology content knowledge (TCK) on the mastery of TPACK, and communication aspects on teamwork skills. Based on the regression test, the result obtained more than $90 \%$, the communication aspect of teamwork skills influenced by TK and TCK. Another finding is that the most dominant external factor that influences teamwork skills is gender.
\end{abstract}

\section{INTRODUCTION}

Mastery of 21st-century skills not only needs to be mastered by students but also teachers. Why is that? The teacher is the primary source who must master these skills to teach them to students. One of the $21^{\text {st }}$ century skills teachers must master is teamwork skills (Valtonen et al., 2021). Therefore, in the education of preservice physics teachers, these skills need to be trained. Teamwork skills are required, especially for later life in the world of work. Future physics teachers who have these skills will get more value in colleagues' eyes and thrive in a collaborative work environment. At work, teachers do not work independently but must join a particular group. For example, a group of "Musyawarah Guru Mata Pelajaran (MGMP)" or "Subject
Teacher Deliberation" is located at the city and provincial levels. MGMP aims to improve the skills of physics teachers.

Teamwork involves dimensions of behavior, attitudes, and cognition that enable teams to function to achieve common goals (Pugh et al., 2014). According to DeChurch and Mesmer-Magnus (2010), the cognition dimension is consistently related to the skills produced, teamwork skills. In line with Mathieu et al. (2008), research explained that when a team does not have extensive knowledge of the task, they will fail if the members cannot trust each other and are unsuccessful in coordinating knowledge sharing.

The knowledge required by preservice physics teachers as an educator's knowledge base for the $21^{\text {st }}$-century is related to 
technology. According to Hussain \& Al Saadi (2019), preservice teachers who have positive experiences, where they often integrate technology, can develop good teamwork. Mastery of technological skills is considered a powerful tool for educational change and reform (Fu, 2013). This technological mastery skill is packaged in technological pedagogical content knowledge (TPACK). Teachers who master the TPACK skills will create more effective learning (Etzkorn, 2018; Hong et al., 2018). By getting TPACK, a teacher can bridge knowledge, practice, and technology to make learning more effective (Wang, 2019). Primarily concerning the mastery of technology, it is seen both as a target for learning itself and as a tool to support $21^{\text {st }}$ century skills by increasing learning opportunities, teamwork, problem-solving, and creativity (Voogt \& Roblin, 2012).

Studies on the factors that influence teamwork skills mostly carried out in nursing, management, and business education. Some example, the learning environment is supported by TeamUP ShortForm (TeamUP-SF) as a self-and peerassessment tool related to teamwork (Vaughan et al., 2019). Team training can improve teamwork and communication skills (Mahmood et al., 2021; Reising et al., 2017). Feedback from colleagues affects teamwork skills (Donia et al., 2018). Belief, emotional intelligence, thinking strategies are the top factors that affect teamwork skills (Bektas \& Sohrabifard, 2013; Gibert et al., 2017; Hastie, 2018; Khosravi et al., 2020). Expected performance on teaching support and development, mostly related to using ICT, positively correlates with teamwork (Gellerstedt et al., 2018; Habibi et al., 2020).

Due to several considerations from previous studies, primarily based on research by Schmutz et al. (2019), it shows that teamwork skills affect general skills in the moderate category. The research, however, is still examining general skills. There has been no research that has focused on the opposite relationship and has focused more on
TPACK, affecting teamwork skills, especially in physics education. Therefore, it is necessary to research to determine the relationship between mastery of TPACK and teamwork skills and the extent to which the effect is. So, the research hypothesis is:

$\mathrm{H}_{0}$ : There is no relationship between TPACK mastery and teamwork skills

$\mathrm{H}_{1}$ : There is a relationship between TPACK mastery and teamwork skills

\section{METHODS}

This study employed the quantitative approach with a non-experimental design, namely causal-comparative. The researcher chose the design to test the effect of a variable on other variables. The sampling technique used was purposive sampling. The sample consisted of 29 preservice physics teachers of the $5^{\text {th }}$-semester, Department of Physics Education, Universitas Sultan Ageng Tirtayasa (UNTIRTA), Banten. Furthermore, four students of the $5^{\text {th }}$-semester, Department of Physics Education, Universitas Mulawarman (UNMUL), East Kalimantan, are members of the 4in 1 IsDB Credit Transfer Program for the academic year 2020/2021. This sample was chosen because students have already received courses related to TPACK. Data collection was carried out from November to December 2020 in the "physics learning multimedia course" at the Department of Physics Education, Universitas Sultan Ageng Tirtayasa.

The data collection method used a questionnaire and an instrument in the form of a questionnaire with a Likert scale. This data collection instrument was used to measure TPACK and teamwork skills. Measurement of TPACK mastery uses modified instruments from Zelkowski et al. (2013), consisting of 38 items, with aspects of technology knowledge (TK), technology content knowledge (TCK), technological pedagogical knowledge (TPK), and technological pedagogical content knowledge (TPACK). This instrument was modified because it wanted to focus more on 
students' mastery of technology. The teamwork skills were measured using instruments from Hobson et al. (2014) that are modified, consisting of 21 items with aspects of participation, communication, constructive handling of differences, leadership, support, and trust. Both instruments were packaged in a web-based survey with the help of Google Forms. Then the data from the google form was transferred into Microsoft Excel 2017. The instrument can be downloaded at the following link: shorturl.at/nFK56.

The TPACK instrument was given before the project was carried out, namely in November 2020, to see the mastery of TPACK from each student. The PjBL model is used as long as students create projects. In practice, all students are formed into seven groups consisting of 4-5 members. Each group carries out a project following the $\mathrm{PjBL}$ stages. The implementation of $\mathrm{PjBL}$ is controlled so that it does not affect the research results. After the project is completed within a month, namely in December 2020, students fill out a second questionnaire to see their teamwork skills. The data collected from these instruments were then processed and analyzed using inferential statistics using Pearson's correlation and regression analysis with IBM SPSS Statistics 24 software. The research stages, in brief, can be seen in Figure 1.

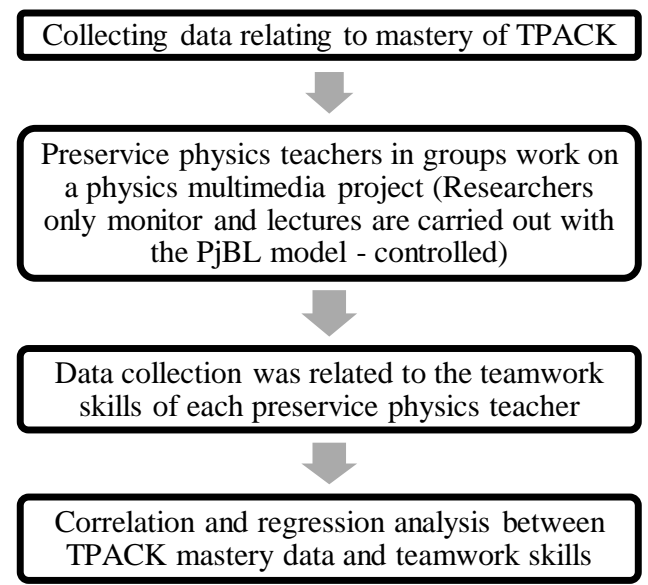

Figure 1. The research flow of the relationship between mastery of TPACK with teamwork skills

\section{RESULTS AND DISCUSSION}

This research was conducted on a physics learning multimedia course by applying the project-based learning (PjBL) model. The PjBL model used follows Keser \& Karagoca (2010). However, this model is not used as a treatment because it is only used to see students' teamwork skills. The researcher did not provide any treatment when conducting the research. Researchers only observe and monitor each student's step. The final project is in the form of multimedia interactive physics learning for high school students in Android and PC applications, adapted to the 2013 curriculum-starting from project planning to evaluate projects carried out by a team of students who have been randomly selected.

The selection of material integrated into interactive multimedia is left to each team, adjusted to the needs analysis that has been carried out. The material chapters, along with the local wisdom selected by the seven student teams, included: 1) the balance of rigid objects - the tradition of "Rangkong"; 2) sound waves - the "Rampak Bedug" tradition; 3) mechanical waves - wave phenomenon on the beach "Anyer Sambolo"; 4) temperature and heat - "Batoe Koewoeng" hot spring; 5) sound waves - "Sampek" musical instrument; 6) linear motion kinematics - "Ki Amuk" cannon; 7) Light waves-the lake phenomenon "Cigaru."

Before starting the project, each student filled out a questionnaire about mastery of TPACK. After the final project is completed, students fill out a questionnaire about teamwork skills. From the data collection results, demographic information from the sample or students involved can be seen in Table 1,

Table 1. Demographic Composition of Sample

\begin{tabular}{ccc}
\hline Aspect & Explanation & Total \\
\hline Age & $19-22$ & 32 \\
& $23-26$ & $(97,0 \%)$ \\
& & $1(3,0 \%)$ \\
\hline GPA & $2,00-2,75$ (Satisfactory) & $1(0,0 \%)$ \\
& $2,76-3,50$ (Very & 26 \\
& satisfactory) & $(78,8 \%)$ \\
\hline
\end{tabular}




\begin{tabular}{ccc}
\hline Aspect & Explanation & Total \\
\hline & $3,51-4,00$ (Cum Laude) & $6(18,2 \%)$ \\
& & \\
\hline Gender & Female & 27 \\
& Male & $(81,8 \%)$ \\
& & $6(18,2 \%)$ \\
\hline Affiliation & Banten Province & 29 \\
& East Kalimantan & $(87,9 \%)$ \\
& Province & $4(12,1 \%)$ \\
\hline
\end{tabular}

The sample ages were in the range of 1922 years. Furthermore, one student falls into the 23-26 range because the student is late starting lectures at college. If based on Piaget's cognitive theory, this age falls into the category of early adulthood. This stage has characteristics including a formal operational way of thinking, a greater quantity of knowledge, and a more systematic and skilled manner. In line with the GPA data obtained, most of the students were in the very satisfying predicate with a percentage of $81.8 \%(\mathrm{~N}=33)$.

Meanwhile, if viewed from the gender side, most of it was dominated by women with a figure of $81.8 \%$. About $87.9 \%$ of students come from Banten Province, Serang City, Serang Regency, Pandeglang Regency, Lebak Regency, and Tangerang Regency. Data relating to the student's area of origin and differences in age, GPA, and gender were analyzed after the main objectives were completed.

\section{TPACK Correlation with Teamwork Skills}

TPACK mastery data and teamwork skills were tested for prerequisites using the Shapiro-Wilk normality test. The analysis results show that the data for each aspect are normally distributed because the significance is more than 0.05 . The results of the normality test can be seen in Table 2 .

Table 2. The Results of the Normality Test

\begin{tabular}{cccc}
\hline No & Aspect & Statistic & Sig. \\
\hline 1 & TK & 0,980 & 0,786 \\
\hline 2 & TCK & 0,960 & 0,252 \\
\hline 3 & TPK & 0,981 & 0,807 \\
\hline 4 & TPACK & 0,985 & 0,928 \\
\hline 5 & Participation & 0,949 & 0,128 \\
\hline 6 & Communication & 0,868 & 0,231 \\
\hline 7 & Constructive handling & 0,799 & 0,218 \\
& of differences & & \\
\hline 8 & Support and trust & 0,973 & 0,573 \\
\hline 9 & Teamwork skills & 0,902 & 0,135 \\
\hline
\end{tabular}

After all the data have been declared as normally distributed, the data can be tested for correlation. The results of the correlation analysis are shown in Table 3.

Table 3. Correlation between Mastery of TPACK and Teamwork Skills

\begin{tabular}{|c|c|c|c|c|c|c|c|c|c|c|}
\hline \multirow[t]{2}{*}{$\begin{array}{l}\text { TPACK } \\
\text { Aspects }\end{array}$} & \multicolumn{2}{|c|}{ Participation } & \multicolumn{2}{|c|}{$\begin{array}{l}\text { Communi- } \\
\text { cation }\end{array}$} & \multicolumn{2}{|c|}{$\begin{array}{c}\text { Constructive } \\
\text { Handling of } \\
\text { Differences }\end{array}$} & \multicolumn{2}{|c|}{$\begin{array}{c}\text { Support and } \\
\text { Trust }\end{array}$} & \multicolumn{2}{|c|}{ Teamwork Skills } \\
\hline & $\mathbf{P}$ & Sig. & $\mathbf{P}$ & Sig. & $\mathbf{P}$ & Sig. & $\mathbf{P}$ & Sig. & $\mathbf{P}$ & Sig. \\
\hline TK & $-0,059$ & 0,744 & $-0,229$ & $0,020 *$ & $-0,230$ & 0,198 & $-0,203$ & 0,257 & $-0,220$ & 0,219 \\
\hline TCK & 0,213 & 0,233 & 0,356 & $0,042 *$ & 0,261 & 0,143 & 0,246 & 0,168 & 0,301 & 0,089 \\
\hline TPK & 0,128 & 0,477 & 0,196 & 0,274 & 0,192 & 0,284 & 0,124 & 0,492 & 0,189 & 0,293 \\
\hline TPACK & 0,044 & 0,81 & 0,070 & 0,700 & 0,024 & 0,896 & 0,073 & 0,687 & $0,061 * *$ & 0,735 \\
\hline
\end{tabular}

P: Pearson's correlation

* Significant value at 0.05

** Pearson's correlation value between TPACK and teamwork skills

Based on Table 3, the correlation value between TPACK and teamwork skills is 0.061 with a significance of 0.735 . This indicates that $\mathrm{H}_{0}$ is accepted, meaning that there is no significant relationship between TPACK mastery of teamwork skills. In general, TPACK is not related to teamwork skills because only a few aspects are correlated when viewed from the results of data analysis. High or low TPACK mastery does not directly affect the teamwork of an individual. The researcher confirmed that 
there were individuals with high TPACK mastery with good teamwork. Nevertheless, there is also the opposite, the TPACK mastery is high, but the teamwork is low.

If explored further, there is a relationship between the two data. Still, it falls into the fragile category - positive correlation value, indicating a close relationship. In line with Hussain and Al Saadi (2019) research results, students who master general skills can collaborate in teams well. Supported by Virtanen et al. (2021) explain that students who enter teacher education have confidence in teaching skills (TPACK) and positively correlated with teamwork. However, suppose you look at every aspect. In that case, there is a significant correlation between the aspects of technological knowledge (TK), technological pedagogical knowledge (TPK) on the TPACK mastery variable with the communication aspect in the teamwork skills variable.

\section{The Influence of Technology Knowledge (TK) Aspects on Communication Aspects}

When viewed based on each aspect, there are several significant correlations because the calculated significance value $<0.05$. The correlation between TK and communication is -0.229 (according to Table 3 ), indicating a weak and inversely proportional (negative) relationship. This can be interpreted, if the TK score increases, the communication value will decrease, and vice versa. With these results, further analysis was carried out by looking for the correlation in each item of the statement on the two variables, which caused a negative correlation. TK is the knowledge of prospective teachers about what and how technology, software, or applications can be used for learning. TK also includes the ability to adapt and learn new technology. The results of further analysis are presented in Table 4.

Table 4. Correlation between aspects of TK and communication

\begin{tabular}{lllll}
\hline No & \multicolumn{1}{c}{ TK Aspect } & \multicolumn{1}{c}{ Communication Aspect } & P & Sig. \\
\hline 1 & $\begin{array}{l}\text { I have the technical skills I need to } \\
\text { use technology (Positive) }\end{array}$ & $\begin{array}{l}\text { I like to give personalized criticism and } \\
\text { condescend to my teammates (Negative) }\end{array}$ & $-0,367$ & 0,036 \\
\hline 2 & $\begin{array}{l}\text { I have the technical skills I need to } \\
\text { use technology (Positive) }\end{array}$ & $\begin{array}{l}\text { I like to start other conversations while } \\
\text { teammates are talking (Negative) }\end{array}$ & $-0,586$ & 0,000 \\
\hline 3 & $\begin{array}{l}\text { When I have problems using } \\
\text { technology, I seek help from other } \\
\text { people (Positive) }\end{array}$ & $\begin{array}{l}\text { I listen attentively (eye contact, } \\
\text { understanding) when teammates talk or } \\
\text { ask for opinions (Positive) }\end{array}$ & 0,010 \\
\hline
\end{tabular}

Table 4 in numbers 1 and 2 shows a negative correlation value of -0.367 and 0.586. If interpreted in general, students who have the skills to use technology tend to have good communication characteristics. Suppose it is related to the statement of every aspect. In that case, students with this category tend not to give personalized criticism or demean their teammates. Also, they tend to be quiet or make noise (create their forums) when their teammates talk. Following the well-known adage in Indonesia, "like rice, the more it is, the more it will bow," meaning that the more knowledgeable, the more polite the behavior. This is in line with the research results by Hussain and Al Saadi (2019), which show that students who have expertise in technology tend to communicate efficiently, especially when discussing and teaching teammates. Although there are often disagreements in discussions over time and concerted efforts, it can resolve these differences and decisions. Supported by Barak (2018) results, it explained that students who are proficient in using technology tend to be flexible in thinking. If they have discussions, they will be more dynamic. Researchers also confirmed these results. At the PjBL stage, especially in designing steps for project completion. At this stage, the team began developing, selecting forms and software to make interactive multimedia. Students with high- 
tech skills play a more significant role. They gave polite input to other team members by suggesting that if you want to design interactive media, you can use Macromedia flash software, articulate storylines, and so on. Experience and motivation play an important role in mastering technology, especially in learning (Nelson \& Hawk, 2020; Tam et al., 2021; Vidergor, 2021).

Whereas in No.3 in Table 4, the correlation value is -0.410 . Same as before is negative. If interpreted, students who are less but like to ask for help from other students who are more skilled would not respond or pay less attention if asked for their opinion. This is because the student is not confident or does not have sufficient knowledge to respond to his teammates' questions. They are also afraid of giving the wrong answer, therefore preferring to look away or be quiet. This implies that teacher education programs should provide facilities or assistance such as easy access to information facilities, support studentcentered learning, prepare a creative learning environment, prepare distance learning, and improve the quality of learning and learning ( $\mathrm{Fu}, 2013)$. This was done to increase student self-confidence. Lowther et al. (2008) also explained three crucial points to improve teaching skills and student confidence in using technology: autonomy, capability, and creativity.

The resulting negative correlation value is positive. This value is generated because there are several questionnaire items designed with negative statements. This is done to anticipate if students give answers arbitrarily. Meanwhile, to see how much influence TC has on communication, it can be seen in Table 5.

Table 5. Regression Value of Analysis Results

\begin{tabular}{ccc}
\hline \multirow{2}{*}{$\begin{array}{c}\text { TPACK } \\
\text { Aspects }\end{array}$} & \multicolumn{2}{c}{ Communication } \\
\cline { 2 - 3 } & $\mathbf{R}$ & $\mathbf{R}^{\mathbf{2}}$ \\
\hline TK & 0,979 & 0,958 \\
\hline TCK & 0,988 & 0,977 \\
\hline
\end{tabular}

Suppose you look at Table 5, especially at the coefficient of determination or $\mathrm{R}^{2}$ value. It can be concluded that the TK aspect has an effect of 0.958 or $95.8 \%$ on the communication aspect. In comparison, the remaining 0.042 or $4.2 \%$ is influenced by other aspects. External aspects can influence because TPACK focuses more on cognitive and behavioral aspects, whereas according to Pugh et al. (2014), teamwork consists of three psychological aspects: attitude, behavior, and cognition. So that there is one aspect that TPACK does not cover, namely attitude. According to several studies, it is suspected that several things influence such as completeness of facilities, the environment, beliefs about the use of technology, motivation, and emotional intelligence (Gellerstedt et al., 2018; Habibi et al., 2020; Nelson \& Hawk, 2020). The factors mentioned earlier are factors that can affect the attitude of an individual, which will affect individual teamwork.

\section{The Correlation between Technology Content Knowledge (TCK) Aspects and Communication}

The relationship between TCK and communication is positive, namely 0.356 (See Table 3), indicating a weak and positive relationship. TCK explains how students can describe the material differently from technology that was not possible before. TCK is also the ability of students to determine and use technology to create new representations in transferring learning materials that have unique characteristics to change the mindset of students. At the PjBL stage, namely the completion of projects with facilitation and monitoring, the researcher saw that students in each team had differences of opinion, especially in combining ideas in revising multimedia that had been made. Products that are made must integrate learning models, local wisdom, and appropriate physics materials. In its implementation, one of the teams had differences of opinion when combining physics material with local wisdom. For example, when students wanted to illustrate the "Ki Amuk" cannon's projectile 
trajectory, namely the Sultanate of Banten cannon stored in the Old Banten museum, they were confused about making the animation. However, students who have good technology skills try to develop ideas and teach other students without offending the team. Animations are made with
Macromedia flash, supported by trajectory illustrations so that it appears that projectile motion is a combination of motion with constant speed and move with constant acceleration. Figure 2 shows an example of the results of good communication between students who have good TCK.

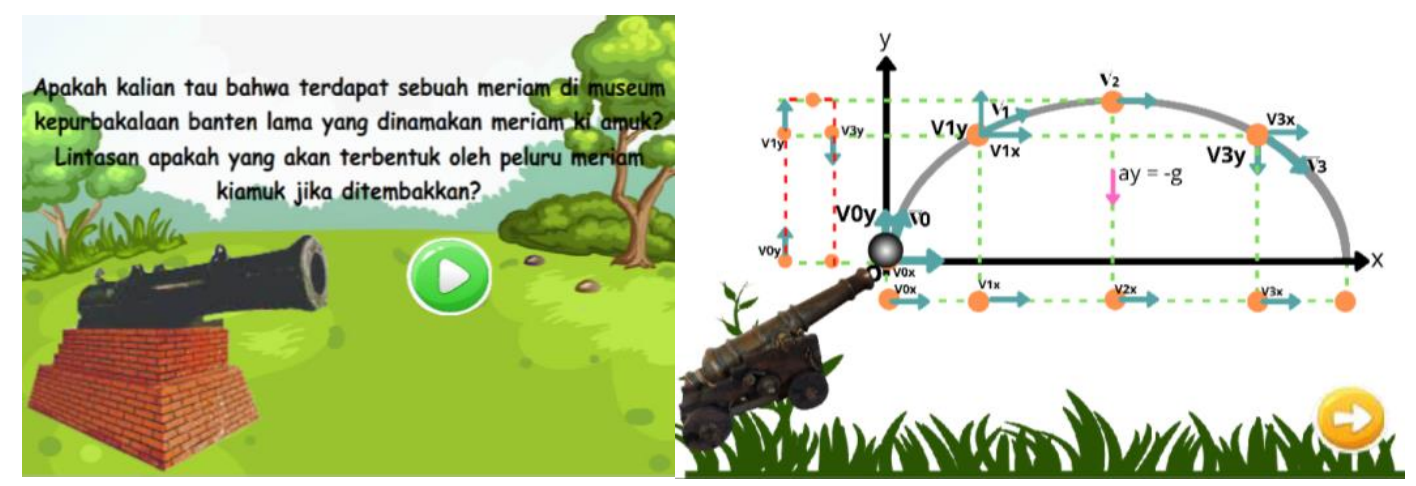

Figure 2. The Results of Students' Team Discussion about Ki Amuk's Cannon

Suppose you look at Table 5, especially on the coefficient of determination or $\mathrm{R}^{2}$ value. It can be concluded that the TCK aspect influences 0.977 or $97.7 \%$ of the communication aspect. In contrast, the rest, 0.023 or $2.3 \%$, is influenced by other aspects. These results are in line with Virtanen et al. (2021), which explains that students who are confident in their ability to teach (content) will be more positive in communicating with groups. Furthermore, tend to be more flexible (Barak, 2018).

\section{The Correlation between Technology Content Knowledge (TCK) Aspects and Communication}

The results of the correlation analysis between external factors that affect teamwork skills can be seen in Table 6 .

Table 6. The Correlation between External Factors and Teamwork Skills

\begin{tabular}{|c|c|c|c|c|c|c|c|c|c|c|}
\hline \multirow{3}{*}{$\begin{array}{l}\text { External } \\
\text { factor }\end{array}$} & \multicolumn{10}{|c|}{ Teamwork aspects } \\
\hline & \multicolumn{2}{|c|}{ Participation } & \multicolumn{2}{|c|}{ Communication } & \multicolumn{2}{|c|}{$\begin{array}{l}\text { Constructive } \\
\text { Handling }\end{array}$} & \multicolumn{2}{|c|}{ Support } & \multicolumn{2}{|c|}{ Teamwork } \\
\hline & $\mathbf{P}$ & Sig. & $\mathbf{P}$ & Sig. & $\mathbf{P}$ & Sig. & $\mathbf{P}$ & Sig. & $\mathbf{P}$ & Sig. \\
\hline Affiliation & $-0,146$ & 0,419 & 0,029 & 0,874 & $-0,103$ & 0,568 & 0,244 & 0,172 & $-0,006$ & 0,971 \\
\hline GPA & 0,064 & 0,724 & $-0,230$ & 0,198 & $-0,127$ & 0,481 & $-0,148$ & 0,412 & $-0,132$ & 0,465 \\
\hline Gender & 0,131 & 0,467 & 0,317 & 0,073 & 0,390 & $0,025^{*}$ & 0,389 & $0,025 *$ & 0,368 & $0,035^{*}$ \\
\hline
\end{tabular}

P: Pearson's correlation

* Significant value at 0.05

From Table 6, it can be seen that external factors also influence teamwork skills. Among several factors, we can see the most dominant factors from the correlation value, namely gender. Gender factors have a significant correlation with several aspects of teamwork skills, namely constructive handling, support, and teamwork as a whole. Researchers also saw that women were more dominant in carrying out their projects during the project creation process. In terms of conflict resolution in groups, female students are also more dominated and the aspect of support. 


\section{CONCLUSION AND SUGGESTION}

The results showed no significant relationship between mastery of TPACK and teamwork skills, as indicated by the Pearson correlation value of 0.061 with a significance of 0.735 . However, if further tested based on every aspect of the two variables, there is a significant correlation between technology knowledge, technology content knowledge on the mastery of TPACK, and communication aspects on teamwork skills. Based on the regression test, it was obtained more than $90 \%$, the communication aspect of teamwork skills was influenced by TK and TCK. The external factor that most dominantly affects teamwork skills is gender. According to Pugh et al. (2014) research, teamwork consists of aspects of attitude, behavior, and cognition, and based on the results of the analysis reinforced by the observations of researchers. It is assumed that women are more balanced in their mastery of attitudes, behaviors, and cognition which correlate with aspects of teamwork than men. Suggestions for the future, this research needs to be reviewed with a larger sample size to be more representative.

\section{REFERENCES}

Barak, M. (2018). Are digital natives open to change? Examining flexible thinking and resistance to change. Computers \& Education, 121(1), 115-123. https://doi.org/10.1016/j.compedu.201 8.01 .016

Bektas, C., \& Sohrabifard, N. (2013). Terms of organizational psychology, personnel empowerment and team working: A case study. Procedia Social and Behavioral Sciences, 82, 886-891.

https://doi.org/10.1016/j.sbspro.2013.0 6.366

DeChurch, L. A., \& Mesmer-Magnus, J. R. (2010). The cognitive underpinnings of effective teamwork: A meta-analysis. Journal of Applied Psychology, 95(1), 32-53.
Donia, M. B. L., O’Neill, T. A., \& Brutus, S. (2018). The longitudinal effects of peer feedback in the development and transfer of student teamwork skills. Learning and Individual Differences, 61, 87-98. https://doi.org/10.1016/j.lindif.2017.11 .012

Etzkorn, K. E. B. (2018). Learning to teach online: Measuring the influence of faculty development training on teaching effectiveness through a TPACK lens. The Internet and Higher Education, 38(7), 28-35.

Fu, J. S. (2013). ICT in education: A critical literature review and its implication. International Journal of Education and Development Using Information and Communication Technology, 9(1), 112-125.

Gellerstedt, M., Babaheidari, S. M., \& Svensson, L. (2018). A first step towards a model for teachers' adoption of ICT pedagogy in schools. Heliyon, 4(9), e00786. https://doi.org/10.1016/j.heliyon.2018. e00786

Gibert, A., Tozer, W. C., \& Westoby, M. (2017). Teamwork, soft skills, and research training. Trends in Ecology and Evolution, 32(2), 81-84. https://doi.org/10.1016/j.tree.2016.11. 004

Habibi, A., Mukminin, A., \& Hadisaputra, P. (2020). Heliyon Science teachers' integration of digital resources in education: A survey in rural areas of one Indonesian province. Heliyon, 6(6), e04631.

https://doi.org/10.1016/j.heliyon.2020. e04631

Hastie, C. (2018). Can the social and emotional skills that underpin effective teamwork be taught to undergraduate midwifery students? Women and Birth, 31 , S10. https://doi.org/10.1016/j.wombi.2018. 08.038

Hobson, C. J., Strupeck, D., Griffin, A., 
Szostek, J., \& Rominger, A. S. (2014). Teaching MBA students teamwork and team leadership skills: An empirical evaluation of a classroom educational program. American Journal of Business Education, 7(3), 191-212.

Hong, B. Van, Tuyen, T., \& Luong, N. T. (2018). Teaching capacity of technology teacher: Apllying in the training program of technology teacher in Vietnam. American Journal of Educational Research, 6(12), 16621667.

Hussain, R. M. R., \& Al Saadi, K. K. (2019). Students as designers of e-book for authentic assessment. Malaysian Journal of Learning and Instruction, 16(1), 23-48.

Keser, \& Karagoca. (2010). Langkahlangkah strategi dalam pembelajaran (I). YRama.

Khosravi, P., Rezvani, A., \& Ashkanasy, N. M. (2020). Emotional intelligence: A preventive strategy to manage destructive influence of conflict in large scale projects. International Journal of Project Management, 38(1), 36-46. https://doi.org/10.1016/j.ijproman.201 9.11.001

Lowther, D. L., Inan, F. A., Strahl, J. D., \& Ross, S. M. (2008). Does technology integration work when key barriers are removed?. Educational Media International, 45, 195-213.

Mahmood, L. S., Mohammed, C. A., \& Gilbert, J. H. V. (2021). Interprofessional simulation education to enhance teamwork and communication skills among medical and nursing undergraduates using the TeamSTEPPS $®$ framework. Medical Journal Armed Forces India, 77, S42S48.

https://doi.org/10.1016/j.mjafi.2020.10 .026

Mathieu, J., Maynard, M. T., Rapp, T., \& Gilson, L. (2008). Team effectiveness 1997-2007: A review of recent advancements and a glimpse into the future. Journal of Management, 34(3), 410-476.

Nelson, M. J., \& Hawk, N. A. (2020). The impact of fi eld experiences on prospective preservice teachers' technology integration beliefs and intentions. Teaching and Teacher Education, $89, \quad 103006$. https://doi.org/10.1016/j.tate.2019.103 006

Pugh, C.M., Cohen, E. R., Kwan, C., \& Cannon-Bowers, J. A. (2014). Investigating the importance of taskwork in team-based assessments. Journal of Surgical Research, 186(2), 677.

https://doi.org/10.1016/j.jss.2013.11.8 60

Pugh, Carla M., Cohen, E. R., Kwan, C., \& Cannon-Bowers, J. A. (2014). A comparative assessment and gap analysis of commonly used team rating scales. Journal of Surgical Research, 190(2), 445-450. https://doi.org/10.1016/j.jss.2014.04.0 34

Reising, D. L., Carr, D. E., Gindling, S., Barnes, R., Garletts, D., \& Ozdogan, Z. (2017). An analysis of interprofessional communication and teamwork skill acquisition in simulation. Journal of Interprofessional Education and Practice, 8, 80-85. https://doi.org/10.1016/j.xjep.2017.07. 001

Schmutz, J. B., Meier, L. L., \& Manser, T. (2019). How effective is teamwork really? The relationship between teamwork and performance in healthcare teams: A systematic review and meta-analysis. BMJ Open, 9(9). https://doi.org/10.1136/bmjopen-2018028280

Tam, H. lin, Kwok, S. Y. C. L., Hui, A. N. N., Chan, D. K. yin, Leung, C., Leung, J., Lo, H., \& Lai, S. (2021). The significance of emotional intelligence to students' learning motivation and academic achievement: A study in 
Hong Kong with a Confucian heritage. Children and Youth Services Review, 121, 105847. https://doi.org/10.1016/j.childyouth.20 20.105847

Valtonen, T., Hoang, N., Sointu, E., Näykki, P., Virtanen, A., Pöysä-Tarhonen, J., Häkkinen, P., Järvelä, S., Mäkitalo, K., \& Kukkonen, J. (2021). How preservice teachers perceive their 21stcentury skills and dispositions: A longitudinal perspective. Computers in Human Behavior, 116(5), 1-9. https://doi.org/10.1016/j.chb.2020.106 643

Vaughan, B., Grace, S., \& Yoxall, J. (2019). Developing teamwork skills in preregistration osteopathy education: A qualitative pilot investigation. International Journal of Osteopathic Medicine, 33-34(6), 46-51. https://doi.org/10.1016/j.ijosm.2019.07 .003

Vidergor, H. E. (2021). Effects of digital escape room on gameful experience, collaboration, and motivation of elementary school students. Computers \& Education, 166, 104156. https://doi.org/10.1016/j.compedu.202 1.104156

Valtonen, T., Hoang, N., Sointu, E., Naykki, P., Virtanen, A., Sanna, J., Kati, M., \& Johanna, P., Kukkonen, J. (2021). How preservice teachers perceive their $21 \mathrm{st}$ - century skills and dispositions: A longitudinal perspective. Computers in Human Behavior. 116 (3), 1-9. https://doi.org/10.1016/j.chb.2020.106 643

Voogt, J., \& Roblin, N. P. (2012). A comparative analysis of international frameworks for 21st century competences: Implications for national curriculum policies. Journal of Curriculum Studies, 44(3), 299-321. https://doi.org/10.1080/00220272.2012 .668938

Wang, C. J. (2019). Facilitating the emotional intelligence development of students: Use of technological pedagogical content knowledge (TPACK). Journal of Hospitality, Leisure, Sport and Tourism Education, 25(1), 100198. https://doi.org/10.1016/j.jhlste.2019.10 0198

Zelkowski, J., Gleason, J., Cox, D. C., \& Bismarck, S. (2013). Developing and validating a reliable TPACK instrument for secondary mathematics preservice teachers. Journal of Research on Technology in Education, 46(2), 173-206. https://doi.org/10.1080/15391523.2013 .10782618 